Esmaeil Pouresmaeili ${ }^{1}$, orcid.org/0000-0002-6686-0877, Arash Ebrahimabadi², orcid.org/0000-0002-1996-2731, Hadi Hamidian', orcid.org/0000-0002-2490-4923
1 - Department of Mining and Geology, Qaemshahr Branch, Islamic Azad University, Qaemshahr, Iran

2 - Department of Petroleum, Mining and Material Engineering, Central Tehran Branch, Islamic Azad University, Tehran, Iran, e-mail: A.Ebrahimabadi@iauctb.ac.ir

\title{
SUSTAINABILITY ASSESSMENT OF AN OPEN-PIT MINE USING A NEW MODEL DEVELOPED BASED ON FOLCHI APPROACH
}

Purpose. Surface mining is one of the main activities that affect the environment, economy and society in its surrounding region. Therefore, it is important to investigate the results of this activity in terms of sustainability assessment. Measuring sustainability of a mine requires a methodology which covers all aspects of mining sustainability. The purpose of the article is to assess the sustainability of career development and determine which components require modification and more consideration.

Methodology. Many researchers have tried to develop certain frameworks to measure sustainable score of mining activities, while some of them are complicated and the rest of them do not cover all aspects of sustainability. In this research work, in order to evaluate the sustainability of an open-pit mine, Folchi method based on Multi-Criteria Decision Making (MCDM) approach was used. With this respect, primarily, influential factors and the impact of each influential factor on the sustainable component of an open-pit mine were investigated.

Findings. In this regard, Anguran lead and zinc open-pit mine was chosen as a case study. A correlation matrix of the weighted impact of each influential factor on each environmental component was built up based on experts' opinion. Afterwards, the magnitude of the influential factors and the impact of each influential factor on the sustainable component of Anguran mine were calculated.

Originality. The results obtained using the Folchi method demonstrated that human health and safety, water quality, air quality, flora and fauna, as well as the surface have become decisive factors in the sustainability of Anguran open-pit mine.

Practical value. Finally, it can be concluded that Anguran quarry is characterized by a significant degree of resilience due to the low level of influence of the influential factors, and there is no need to modify any influential factors.

Keywords: sustainability, sustainable development, Folchi method, lead and zinc mine, Anguran

Introduction. Minerals have always been among the basic needs of human beings. Owing to the exponential increase in population on earth, demands for minerals, especially metals, are progressively augmented; as a result, large quantities of minerals are extracted from mines every day, i.e., over 800000 tonnes of minerals per mine [1]. The extraction of more minerals from mines enhances the creation of waste materials, leading to much more land pollution. Furthermore, more mining wastes, including waste rocks and tailings, are produced as low-grade minerals are dugout. Since the environment plays a critical role in sustainability, its perseverance is of crucial importance. However, mining operations are directly or indirectly affected at all stages, from exploration to production. Compared to mineral exploration, mineral exploitation has considerably more significant impacts on the environment. In a similar vein, mineral processing exerts more adverse effects on the environment than ore extraction $[2,3]$. The economic profitability of mineral production, i. e., the mining economy, is of great significance because economically speaking, it is not reasonable to initiate projects which are not profitable enough. In addition to the mining economy, social issues are determining factors in the successful accomplishment of projects.

For instance, when new projects start in the mine area, several job opportunities are created for the people living in that region, which increases their life expectancy. Hence, determining factors affecting the sustainability of mining projects gain paramount importance. Over the last few decades, attention has been directed toward assessing the sustainable development of mining projects. Several criteria for quantifying mining sustainability have been propounded by Folchi [4], which is based on Multi-Criteria Decision Making (MCDM) [5-7]. In the approach Folchi proposes, instead of the score obtained for each component, to compute the score achieved for each criterion in a $10 \times 10$ matrix. Then, the score of each component is calculated as the sum of the scores of the criteria in that component. Another series of criteria are propounded for each principle of sustainable development by Laurence [8].

(c) Esmaeil Pouresmaeili, Arash Ebrahimabadi, Hadi Hamidian, 2021
Various researchers have used the criteria offered by Folchi and Laurence to introduce new methods for quantifying the sustainable development of mines [9-11]. As a result of their attempts, some methods have been put forth to compute the degree of mining sustainability. One drawback of the Folchi approach is that no unique score is obtained for sustainability; in some of his studies, Philips [12, 13] endeavors to eliminate this problem by modifying this approach. Another point is that many studies have focused on some principles of mining sustainability, especially environmental or socio-economic factors, and have ignored other principles [14-16]. Another downside of the Folchi and Laurence methods is that no upper and lower bounds are calculated for mining sustainability [1719]. Nowadays the environmental impact assessment is so important for all countries [20]. The present study aimed to introduce a method for the quantitative assessment of mining sustainability, compute the sustainability score of open-pit mines, and determine the possible upper and lower sustainability bonds for these mines. The achieved value represents the degree of the sustainability condition of open-pit mines considering the possible magnitude ranges.

Although the previously cited studies have provided valuable information on mining sustainability, they have merely investigated certain environmental effects. Apart from the Folchi approach, the propounded assessment methods of sustainability are restricted in their scope of impact; in other words, they only gauge the effect of mineral operations on one or two aspects of the environment [21]. In the Folchi approach, many environmental impacts of mining processing, including fly rock, air noise, water pollution, and air pollution, are included, and gathering data and analyzing them are not complicated [22]. The current study was designed to develop a new model for sustainable development, focus on the main pillars of sustainability, and use this method to evaluate open-pit mines. In order to validate the model, Angouran Lead and Zinc mine is chosen as a case study.

Angouran Lead and Zinc Mine is placed in Dandi, one of Zanjan provinces, Iran. It is located $125 \mathrm{~km}$ southwest of Zanjan, the capital city of Zanjan province, and $300 \mathrm{~km}$ northwest 
of Tehran, Iran's capital city. Regarding the production of lead and zinc, this Mine has the first rank in the Middle East. Considering the quality of its mineral deposits, it is regarded as one of the best mineral resources. It contains the following three types of minerals:

1) oxides placed at the highest layer of the deposit;

2) sulfur located at the lowest layer of this deposit;

3) a combination of both placed in the middle of these two layers. The location of this Mine is presented in Fig. 1.

Methods. The present study aims at determining the degree of sustainable development of an open-pit mine. To this end, a model is developed using the Folchi approach. In this model, new factors are also added to include all facets of mining operations.

The cost of mine production is one of the effective factors in sustainability. Production cost is a negative economic factor. The increase in mining operations brings about less mine profitability because the more capital expenditures are, the less the overall production cost is; one way to diminish the adverse effects of production cost is to enhance capital expenditures.

Another negative factor is resource depletion since it results in mine closure and the unemployment of those who work in mines; therefore, it is regarded as one of the socio-economic factors. To measure the impact coefficient of resource depletion, three states are defined for this factor using the time required for one's emigrating to a new area and being employed.

Groundwater-surface water interface leads to the pollution of both surface and underground water; considered as a negative factor. As obvious, water is one of the fundamental needs of human life. Its pollution has detrimental effects on it; as a result, water pollution, as a critical environmental factor, should be detected and prevented as soon as possible.

Mine economy is directly under the influence of the level of grade-tonnage uncertainty. The grade-tonnage curves reflect the degree of risk and uncertainty, and significant variance in these curves indicates that the mining economy is not at a satisfactory level. It is possible to develop this poor condition by using more exploration data without considering the computational errors in reserve-grade estimations. Being related to the mining economy, this factor is deemed as an economic factor.

All parts of the mining processing result in air pollution. Every sector of mining operation, for instance, drilling, blasting, loading, hauling, crushing, milling, and ore processing, emits a considerable amount of dust and gas, especially green-

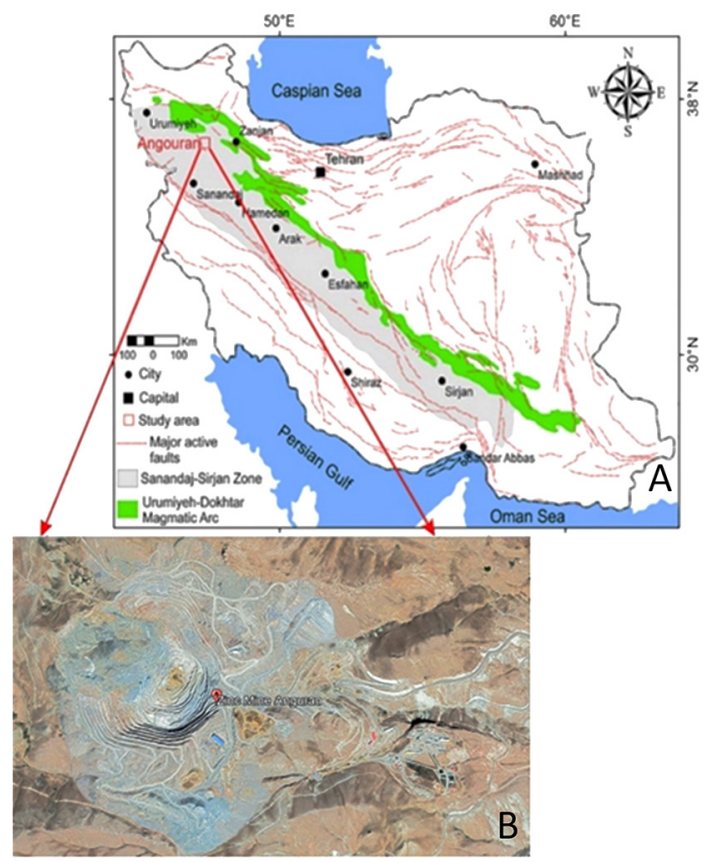

Fig. 1. Location of Angouran Lead and Zinc Mine [23] house gases. Hence, these sectors should take any measures to reduce air pollution. These measures utilize renewable energy resources in mining processing, filtering emitted gases, and spraying water. In dust control concepts, water spray is introduced as a critical technique to diminish dust emissions and maintain the health and safety of people working in mines and their surrounding areas. As dust-gas emissions impact the environment, this factor is classified as an environmental factor.

Annual waste tonnage production is the amount of waste created annually as a result of mining operations. Mining waste and tailings are among the major sources of environmental pollution. Regarding the scale of mining, the larger the mine is, the greater the environmental pollution is. Environmental pollution is divided into three states based on annual waste tonnage generation.

Another impacting factor is the degree of vegetation coverage in mining regions. It is regarded as a negative factor as the more the vegetation coverage in mining areas is, the greater the ecology of those areas is adversely affected. Consequently, vegetation coverage is divided into three states, and in its calculation, vegetation coverage percentage is used [24].

Economically speaking, income plays a crucial role in sustainability maintenance. Several elements, including the price of minerals and their market demands, impact the amount of income. They invest their money in these projects only when financial investors are assured that profits gained from mining projects are more than the risk-free rate. Attracting more investors leads to more significant investment, which reduces the total production cost and enhances profitability. Based on what was stated, three states are defined for income as an economic factor, considering the degree of the profitability of projects.

Progressive reclamation, or rehabilitation, is the post-closure activity for mining processing to minimize the adverse influence of mining operations on the environment. Reclamation, as an environmental factor, is deemed as an indispensable part of modern mining owing to its positive social effects on the environment, including restoring the visual beauty of mining areas or creating beautiful sceneries in mining areas via landscape reclamation.

One of the significant social impacts of mining processing is that it encourages local people to stay in their region rather than immigrating to other areas. Mining sites are usually isolated, remote, and undeveloped areas where local people have difficulty finding a job. Through mining projects, job opportunities are created for these people, which prevents them from abandoning their hometown and immigrating to another area. The more significant a business is, the more job positions there are; more indigenous people are needed to occupy these jobs. This creates a good condition for local people and encourages them not to immigrate to another region. The number of its workforce determines the size of a business. This factor is divided into three states concerning the size of the business [25].

Furthermore, local people's life expectancy and living standards increase due to their being employed and earning enough money. Another advantage of mining operations is improving local people's job skills since they are trained for their job. Local people's well-being promotes. Three states are defined to prevent immigration about the number of job positions created in mining areas. Similarly, three conditions are considered for life expectancy based on the living standards of mining regions. These factors, i.e. the prevention of immigration and life expectancy, are deemed social factors. Three states are also defined for job skill development, considering the number of hours spent on training courses. Three states are introduced for transfer infrastructure and welfare facilities considering the infrastructure of mining areas. Various countries have different contributions of mining to GDP. There are several countries with higher contributions of mining to GPD, for example, Chile. As evident, any mine in any country contributes to the GDP of that country and has a small share in it; however, in the current study, to enhance the comparability of the total mining 
share of GDP across different countries, the annual mine income is divided by the total mining share of GDP. This ratio normalizes conditions for countries whose total mining sector share of GDP differs. Three states have defined the share of GDP considering mines with different scales.

In the Folchi approach, two ways are used to collect data: expert opinions and MCDM models. In the MCDM models, criteria are included, and various options are assessed, selected, and organized in order of priority based on these criteria. These criteria, frequently utilized for weighting, reveal different aspects of the options. In effect, they provide sufficient information on the existing options and help you select the best one, leading to the optimum level of benefits and success. As mentioned above, one of the upsides of the Folchi approach is that it considers all the sustainability factors involved in mining processing. Generally, it introduces seven phases of measuring sustainable development. In the first phase, all the terms related to sustainability, such as geology, hydrology, economy, human health, and human safety, are described (phase 1). Then, the effective factors in improving current sustainable conditions considering mine life are detected (phase 2). After that, the possible magnitude ranges of the influential factors seen in phase 2 are measured (phase 3 ). In the next phase, each sustainable condition is modified concerning mining processing (phase 4). Afterward, each sustainable parameter is correlated with each component (phase 5). Then, the degree of influence each detected factor has is gauged based on the possible magnitude range obtained in phase 3 (phase 6). In the end, the weighted impact values obtained for each component are added up (phase 7).

The proposed method can be summarized as:

Step 1: describing terms related to sustainability (components and factors that affect components).

Step 2: assign each factor's impact factor on each component and normalize these values by 10 based on Experts' Opinions. In this context, the experts refer to mining engineers, academic professors, public and private sector stockholders, and non-governmental organizations. The normalized value has \pm 0.008 tolerance.

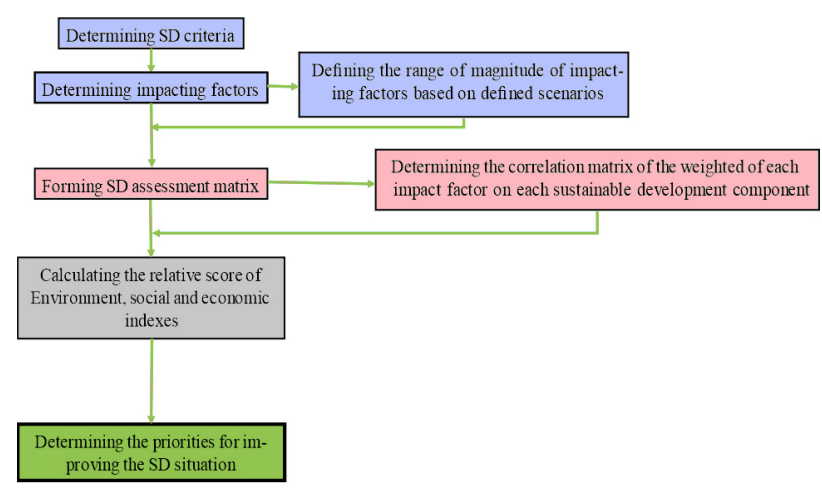

Fig. 2. The framework of the proposed model

Step 3: based on each condition of the mine, the magnitudes are chosen for each factor. These magnitudes are also based on experts' opinions, which is familiar with mines atmosphere. Experts assigned the magnitude of the impact factors. In contrast, the score of the mining activities' impacts on the sustainable development component was calculated based on the correlation matrix.

Step 4: in this step, each chosen magnitude for each factor is multiplied by each component related to that factor. Afterward, the summation was performed on each column to reach that component's sustainability level.

Step 5: in this step, we consider the maximum summation mentioned in step 4 as the critical components that negatively affect sustainability.

Based on the 5 steps defined for this model, Fig. 2 illustrates the framework for the proposed approach.

Following this approach, the impact parameters in mining processing were first detected and defined for the area under investigation (Angouran Lead and Zinc Mine) in the present study. Fourteen parameters, including human health and safety, use of territory, air quality, water quality, flora and fauna, social relationship, surface water, underground water, landscape, noise, economy, and soil degradation, were identified. In

Explanation of impacting factors

\begin{tabular}{|c|l|c|l|}
\hline No. & \multicolumn{1}{|c|}{ Impacting factors } & $\begin{array}{c}\text { Kind of } \\
\text { impact } \\
(+/-)\end{array}$ & \\
\hline 1 & Production cost & - & Increase the cost of mining operations brings about less mine profitability \\
\hline 2 & Resource depletion & - & Reduce mine life and effect on the social index \\
\hline 3 & $\begin{array}{l}\text { Interface with surface and } \\
\text { underground water }\end{array}$ & - & Increase water pollution, and it can pollute the yields around of the Mine \\
\hline 4 & Grade-tonnage uncertainty & - & Can jeopardize the desired goals in the mining plan and cause the project failure \\
\hline 5 & Dust and gas emission & - & Increase air pollution, and it can damage the life quality of around the Mine \\
\hline 6 & Annual waste tonnage production & - & $\begin{array}{l}\text { Mining waste and tailings are among the significant sources of environmental } \\
\text { pollution }\end{array}$ \\
\hline 7 & Vegetation coverage & - & $\begin{array}{l}\text { Vegetation coverage in mining areas, the greater the ecology of those areas is adversely } \\
\text { affected }\end{array}$ \\
\hline 8 & Income & + & Increase the profit and direct effect on the economic index \\
\hline 9 & Reclamation & + & Increase environment index of sustainable development in mining \\
\hline 10 & Prevention of immigration & + & Help localization with finding job and effect on the social index \\
\hline 11 & $\begin{array}{l}\text { Transfer infrastructure to the mine } \\
\text { region }\end{array}$ & + & $\begin{array}{l}\text { Increase infrastructures of a mining region. It affects the life quality of local people } \\
\text { and helps to make better lifestyle }\end{array}$ \\
\hline 12 & Increase in life expectancy & + & Living standards increase as a result of their being employed and earning enough money \\
\hline 13 & $\begin{array}{l}\text { Increasing job skills in the mining } \\
\text { region }\end{array}$ & + & $\begin{array}{l}\text { Increase jobs concerning the number of job positions created in mining areas and } \\
\text { effect on the social index }\end{array}$ \\
\hline 14 & GDP shares of mining sectors & + & Increase the wealth of country and effect on total GDP \\
\hline
\end{tabular}


The correlation matrix of the weighted of each impact factor on each sustainable component

\begin{tabular}{|c|c|c|c|c|c|c|c|c|c|c|c|}
\hline Impact Factors & 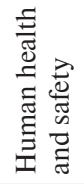 & 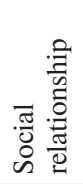 & 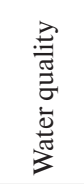 & 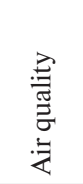 & 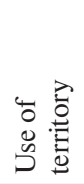 & 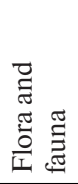 & 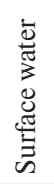 & 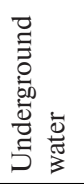 & 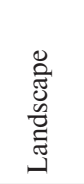 & $\begin{array}{l}0 \\
\frac{0}{0} \\
z\end{array}$ & 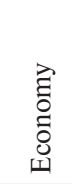 \\
\hline Production cost & 0 & 0 & 0 & 0 & 0 & 0 & 0.5 & 1.111 & 0 & 0 & 0.909 \\
\hline Resource depletion & 0 & 0.556 & 0 & 0.667 & 2.222 & 1 & 2 & 2.222 & 2.273 & 0 & 0.682 \\
\hline Interface with surface and underground water & 1.25 & 0 & 3.125 & 0 & 0.556 & 2 & 2.5 & 5.556 & 2.273 & 0 & 0.455 \\
\hline Uncertainty (grade and Tonnage) & 0 & 0 & 0 & 0 & 1.111 & 0 & 1 & 0 & 0 & 0 & 1.136 \\
\hline Dust and gas emission & 0.938 & 0 & 1.25 & 2.667 & 0 & 0 & 0 & 0 & 0.455 & 1.667 & 0.227 \\
\hline Annual waste tonnage production & 0 & 0 & 1.25 & 2 & 1.111 & 1.5 & 1 & 0 & 1.364 & 3.333 & 0.909 \\
\hline Vegetation overage & 1.25 & 1.111 & 0.625 & 0.667 & 1.111 & 2 & 0.5 & 0 & 0.455 & 0 & 0.227 \\
\hline Income & 1.25 & 1.111 & 0 & 0 & 0 & 0 & 0 & 0 & 0.455 & 1.667 & 0.909 \\
\hline Reclamation & 0.938 & 0.556 & 1.25 & 1.333 & 0.556 & 2 & 1.5 & 0 & 0.909 & 0 & 0.682 \\
\hline Prevention of immigration & 0.625 & 2.222 & 0 & 0 & 0.556 & 0 & 0 & 0 & 0 & 1.667 & 0.682 \\
\hline Transfer infrastructure to the mine region & 0.938 & 0.556 & 1.25 & 1.333 & 1.111 & 0.5 & 0.5 & 0 & 1.364 & 0 & 0.682 \\
\hline Increase in life expectancy & 1.25 & 1.111 & 0 & 0 & 0 & 0 & 0 & 0 & 0 & 0 & 0.682 \\
\hline Increasing job skills in mining region & 0.938 & 1.111 & 0 & 0 & 0 & 0 & 0 & 0 & 0 & 0 & 0.909 \\
\hline Share of mining GDP & 0.625 & 1.667 & 1.25 & 1.333 & 1.667 & 1 & 0.5 & 1.111 & 0.455 & 1.667 & 0.909 \\
\hline Total & 10 & 10 & 10 & 10 & 10 & 10 & 10 & 10 & 10 & 10 & 10 \\
\hline
\end{tabular}

Table 3

The range of magnitudes for the impact factors

\begin{tabular}{|c|c|c|c|}
\hline No. & Factor & Condition & Magnitude \\
\hline \multirow[t]{3}{*}{1} & \multirow[t]{3}{*}{ Production Cost } & The production cost is more than the regional mining cost & $7-10$ \\
\hline & & The production cost is around regional mining cost & $2-6$ \\
\hline & & The production cost is less than the regional mining cost & $0-2$ \\
\hline \multirow[t]{3}{*}{2} & \multirow[t]{3}{*}{$\begin{array}{l}\text { Resource } \\
\text { Depletion }\end{array}$} & $\begin{array}{l}\text { Life of Mine is less than } 5 \text { years. The employees need to think hard about immigration and finding a } \\
\text { new job }\end{array}$ & $8-10$ \\
\hline & & $\begin{array}{l}\text { Life of Mine between } 5 \text { and } 15 \text { years. The employees have enough time for immigration and finding } \\
\text { a new job }\end{array}$ & $4-7$ \\
\hline & & $\begin{array}{l}\text { Life of Mine is more than } 15 \text { years. The employees do not need to think about immigration and } \\
\text { finding a new job for a long time }\end{array}$ & $1-4$ \\
\hline \multirow[t]{3}{*}{3} & \multirow{3}{*}{$\begin{array}{l}\text { Interface with } \\
\text { surface and } \\
\text { underground water }\end{array}$} & Interference with surface and underground water and water pollution are uncontrollable & $7-10$ \\
\hline & & Interference with surface and underground water and water pollution are controllable & $3-6$ \\
\hline & & The Mine does not have any interference with surface and underground water & $1-3$ \\
\hline \multirow[t]{3}{*}{4} & \multirow[t]{3}{*}{$\begin{array}{l}\text { Uncertainty (grade } \\
\text { and Tonnage) }\end{array}$} & $\begin{array}{l}\text { A significant variance accompanies grade and tonnage estimation, and the exploration plan is not } \\
\text { sufficient at all }\end{array}$ & $7-10$ \\
\hline & & Grade and tonnage estimation have medium variance, and the exploration plan is not sufficient & $2-6$ \\
\hline & & Grade and tonnage estimation have a little variance, and the exploration plan is sufficient & $0-2$ \\
\hline \multirow[t]{3}{*}{5} & \multirow{3}{*}{$\begin{array}{l}\text { Dust and gas } \\
\text { emission }\end{array}$} & Water spraying and gases filtration systems are not established in the mine and mill & $8-10$ \\
\hline & & Water spraying and gases filtration systems are limitedly established in the mines and mill & $4-7$ \\
\hline & & Water spraying and gases filtration systems are fully established in the mine and mill & $1-4$ \\
\hline \multirow[t]{3}{*}{6} & \multirow{3}{*}{$\begin{array}{l}\text { Annual waste } \\
\text { tonnage } \\
\text { production }\end{array}$} & Annual tail and stripped waste tonnage are higher than 5 million tonnes per year & $7-10$ \\
\hline & & Annual tail and stripped waste tonnage are between 1 to 5 million tonnes per year & $2-6$ \\
\hline & & Annual tail and stripped waste tonnage are below the 1 million tonnes per year & $0-2$ \\
\hline \multirow[t]{3}{*}{7} & \multirow{3}{*}{$\begin{array}{l}\text { Vegetarian } \\
\text { coverage }\end{array}$} & Development of vegetation is low; coverage scale is less than $20 \%$ & $7-10$ \\
\hline & & Development of vegetation is in a moderate degree; coverage scale is $20-60 \%$ & $2-6$ \\
\hline & & The coverage scale is more than $60 \%$ & $0-2$ \\
\hline \multirow[t]{3}{*}{8} & \multirow[t]{3}{*}{ Income } & Mine profit is negative & $7-10$ \\
\hline & & Mine profit is positive and less than the risk-free rate & $2-6$ \\
\hline & & Mine profit is positive and more than the risk-free rate & $0-2$ \\
\hline
\end{tabular}


End of Table 3

\begin{tabular}{|c|c|c|c|}
\hline \multirow[t]{3}{*}{9} & \multirow[t]{3}{*}{ Reclamation } & The Mine does not have any reclamation plan & $8-10$ \\
\hline & & The progressive reclamation plan is going on, but it is behind schedule & $4-7$ \\
\hline & & The progressive reclamation plan is going on from the first stage of mining & $1-4$ \\
\hline \multirow[t]{3}{*}{10} & \multirow{3}{*}{$\begin{array}{l}\text { Prevention of } \\
\text { immigration }\end{array}$} & Small business (less than 99 job positions) & $7-10$ \\
\hline & & Medium-sized business (between 100-499 job positions) & $3-6$ \\
\hline & & Large business (more than 500 job positions) & $1-3$ \\
\hline \multirow[t]{3}{*}{11} & \multirow{3}{*}{$\begin{array}{l}\text { Transfer } \\
\text { infrastructure to } \\
\text { the mine region }\end{array}$} & There are all infrastructures in the mine region, and the mining sector only uses infrastructures & $7-10$ \\
\hline & & $\begin{array}{l}\text { There are limited infrastructures in the mine region, and the mining sector constructs the rest of } \\
\text { the required infrastructures }\end{array}$ & $2-6$ \\
\hline & & $\begin{array}{l}\text { There are no infrastructures in the mine region, and the mining sector constructs all required } \\
\text { infrastructures }\end{array}$ & $0-2$ \\
\hline \multirow[t]{3}{*}{12} & \multirow[t]{3}{*}{$\begin{array}{l}\text { Increase in life } \\
\text { expectancy }\end{array}$} & $\begin{array}{l}\text { Employees' salary is lower than regional standard wage, and their lifestyle is more down than } \\
\text { regional living standards }\end{array}$ & $8-10$ \\
\hline & & $\begin{array}{l}\text { Employees' salary is equal to regional standard wage, and their lifestyle is similar to regional living } \\
\text { standards }\end{array}$ & $4-7$ \\
\hline & & $\begin{array}{l}\text { Employees' salary is lower than regional standard wage, and their lifestyle is higher than regional } \\
\text { living standards }\end{array}$ & $1-4$ \\
\hline \multirow[t]{3}{*}{13} & \multirow{3}{*}{$\begin{array}{l}\text { Increasing job } \\
\text { skills in the mining } \\
\text { region }\end{array}$} & Training has not been provided to the workforce, and the skilled worker is provided elsewhere & $7-10$ \\
\hline & & Training has been provided to the workforce limitedly & $2-6$ \\
\hline & & Training has been provided to the workforce extensively & $0-2$ \\
\hline \multirow[t]{3}{*}{14} & \multirow{3}{*}{$\begin{array}{l}\text { Mine share from } \\
\text { mining GDP }\end{array}$} & The Mine has to share less than 0.1 percent of the country mining GDP & $7-10$ \\
\hline & & The Mine has a share between 0.1 up to 0.5 percent of the country mining GDP & $2-6$ \\
\hline & & The Mine has shared more than 0.5 percent of the country mining GDP & $0-2$ \\
\hline
\end{tabular}

Table 4 culated error was \pm 0.008 . Table 3 presents the possible magni-

The experts' team characteristics

\begin{tabular}{|l|l|c|}
\hline \multicolumn{1}{|c|}{ Skill } & \multicolumn{1}{|c|}{ Education } & $\begin{array}{c}\text { Number } \\
\text { of persons }\end{array}$ \\
\hline Academic persons & Ph.D & 2 \\
\hline Public sector's stakeholders & Ph.D & 1 \\
\cline { 2 - 3 } & M.Sc & 3 \\
\hline Private sector's stakeholders & M.Sc & 2 \\
\hline Mining engineers & Ph.D and Ph.D students & 4 \\
\cline { 2 - 3 } & M.Sc and M.Sc students & 3 \\
\hline $\begin{array}{l}\text { Non-governmental } \\
\text { organizations }\end{array}$ & M.Sc & 2 \\
\cline { 2 - 3 } & B.Sc & 1 \\
\hline
\end{tabular}

the next stage, the extent to which each sustainable index (in) directly impacted each of these parameters was measured. To quantify the influence of these parameters, a rating system generating different possible scenarios was used. The impact parameters were selected, and the values obtained for them were added up. This achieved value was considered as the total impact of mining on each sustainable index. The results revealed 14 effective factors: 1) production cost; 2) resource depletion; 3 ) interfaces with surface and underground water interface; 4) grade-tonnage uncertainty; 5) dust and gas emission; 6) annual waste tonnage production; 7) vegetation coverage; 8) income; 9) progressive reclamation; 10) prevention of immigration; 11) transfer infrastructure to the mine region; 12) increasing job skills in the mining region; 13) development of job skills in mining areas; 14) GDP shares of mining sectors. The summarized explanation of impacting factors is shown in Table 1.

The next stage involved identifying the possible scenarios for each impact parameter and estimating the magnitude range for each scenario of the impact parameters. The various possible scenarios for each factor and their ranges of magnitude are provided in Table 3. As indicated in Table 2, the cal- tude range of each effective parameter.

Results. The results of the previous studies have verified 347 mining sectors associated with sustainable development indices. Technically speaking, these indices should evaluate available options with respect to the criteria of sustainable development. As pointed out before, in the developed model, 14 effective sustainability factors were included. To determine the factors considerably affecting the sustainability development of Angouran Lead and Zinc Mine, each factor's upper and lower bonds (Table 3) were taken into account. The obtained impact factors are reported in Table 5. After that, one range was chosen among the magnitude ranges provided in Table 3 , and based on that magnitude range, and the $10 \times 10$ matrix was formed for the impact factors. 18 experts filled the magnitude form for Angouran lead and zinc mine. The number and characterization of experts' teams that fill the form are shown in Table 4 . The final version of this matrix is presented in Table 5.

The results of Table 5 have been graphically provided in Fig. 3, which negatively shows each component's sustainability level. The normalized values are also plotted in Fig. 4.

The results show that using the proposed Folchi approach, among 11 components of sustainable development, five of them had the highest sustainable impact, and six of them had a low impact, as presented in Fig. 3 and Table 5. These five components include human health and safety, water quality, air quality, flora and fauna, and surface. To confirm their significant actual impact, those components mentioned above should attain a total impact rate of 100 ; however, a closer analysis indicates that the remaining components out of $11 \mathrm{com}-$ ponents mentioned in the first line of this section (six components) obtained low impact values. Insignificant results were found for the actual impacts of the remaining components of sustainability (social relationship, use of territory, underground water, landscape, noise, and economy). These findings reveal that future mining operations would not bring about any considerable changes in the sustainable development of the surrounding regions of this Mine. Fig. 4 is based on the degree 
Magnitude range of effective factors along with their impact on sustainable components

\begin{tabular}{|c|c|c|c|c|c|c|c|c|c|c|c|c|}
\hline Impact factors & 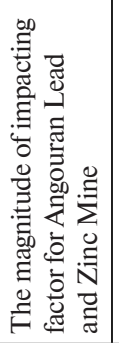 & 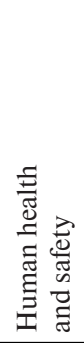 & 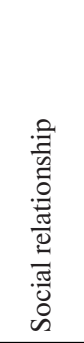 & 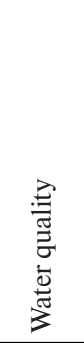 & 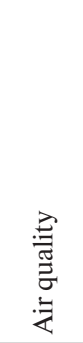 & 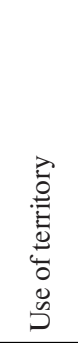 & 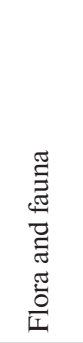 & 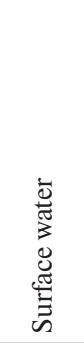 & 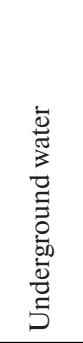 & 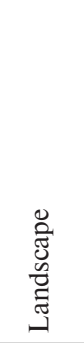 & $\begin{array}{l}0 \\
\frac{n}{0} \\
z\end{array}$ & 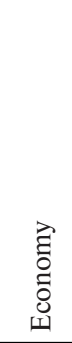 \\
\hline Production cost & 4 & 0.00 & 0.00 & 0.00 & 0.00 & 0.00 & 0.00 & 2.00 & 4.44 & 0.00 & 0.00 & 3.64 \\
\hline Resource depletion & 2 & 0.00 & 1.11 & 0.00 & 1.33 & 4.44 & 2.00 & 4.00 & 4.44 & 4.55 & 0.00 & 1.36 \\
\hline $\begin{array}{l}\text { Interface with surface and } \\
\text { underground water }\end{array}$ & 2 & 2.50 & 0.00 & 6.25 & 0.00 & 1.11 & 4.00 & 5.00 & 11.11 & 4.55 & 0.00 & 0.91 \\
\hline Uncertainty (grade and tonnage) & 1 & 0.00 & 0.00 & 0.00 & 0.00 & 1.11 & 0.00 & 1.00 & 0.00 & 0.00 & 0.00 & 1.14 \\
\hline Dust and gas emission & 3 & 2.81 & 0.00 & 3.75 & 8.00 & 0.00 & 0.00 & 0.00 & 0.00 & 1.36 & 5.00 & 0.68 \\
\hline Annual waste tonnage pr & 4 & 0.00 & 0.00 & 5.00 & 8.00 & 4.44 & 6.00 & 4.00 & 0.00 & 5.45 & 13.33 & 3.64 \\
\hline Vegetation coverage & 5 & 6.25 & 5.56 & 3.13 & 3.33 & 5.56 & 10.00 & 2.50 & 0.00 & 2.27 & 0.00 & 1.14 \\
\hline Income & 1 & 1.25 & 1.11 & 0.00 & 0.00 & 0.00 & 0.00 & 0.00 & 0.00 & 0.45 & 1.67 & 0.91 \\
\hline Reclamation & 6 & 5.63 & 3.33 & 7.50 & 8.00 & 3.33 & 12.00 & 9.00 & 0.00 & 5.45 & 0.00 & 4.09 \\
\hline Prevention of immigration & 1 & 0.63 & 2.22 & 0.00 & 0.00 & 0.56 & 0.00 & 0.00 & 0.00 & 0.00 & 1.67 & 0.68 \\
\hline $\begin{array}{l}\text { Transfer infrastructure to the mine } \\
\text { region }\end{array}$ & 2 & 1.88 & 1.11 & 2.50 & 2.67 & 2.22 & 1.00 & 1.00 & 0.00 & 2.73 & 0.00 & 1.36 \\
\hline Increase in life expectancy & 4 & 5.00 & 4.44 & 0.00 & 0.00 & 0.00 & 0.00 & 0.00 & 0.00 & 0.00 & 0.00 & 2.73 \\
\hline Increasing job skills in mining region & 3 & 2.81 & 3.33 & 0.00 & 0.00 & 0.00 & 0.00 & 0.00 & 0.00 & 0.00 & 0.00 & 2.73 \\
\hline Share of mining GDP & 2 & 1.25 & 3.33 & 2.50 & 2.67 & 3.33 & 2.00 & 1.00 & 2.22 & 0.91 & 3.33 & 1.82 \\
\hline Total & & 30.00 & 25.56 & 30.63 & 34.00 & 26.11 & 37.00 & 29.50 & 22.22 & 27.73 & 25.00 & 26.82 \\
\hline
\end{tabular}

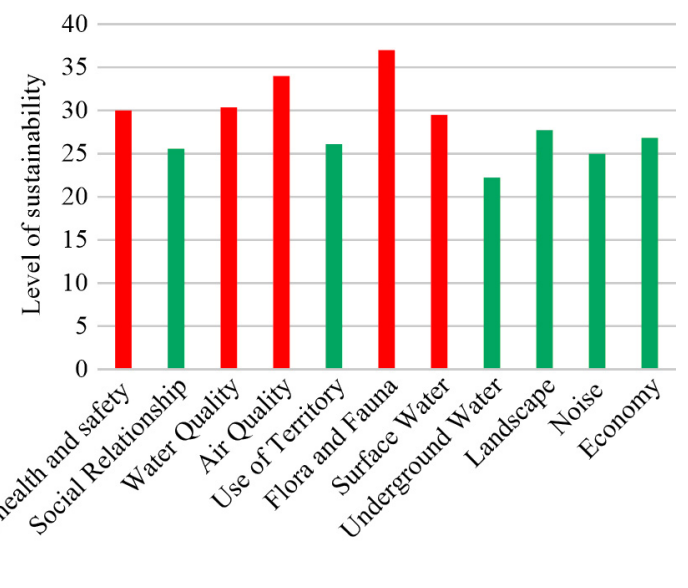

Fig. 3. Results of sustainable impact measurement

of sustainable development reported in Fig. 3 and is reported in percentage (data normalization from 0 to 100 ).

Conclusions. Open-pit mining has significant impacts on mined land and surrounding area, particularly on the environment and society and economy. According to sustainable development regulations, mining, which is considered a country's primary sector, should be sustainable. In this research work, with an idea from the Folchi approach, a new sustainability assessment model was developed for open-pit mine projects. With this respect, primarily, impact factors and the impact of each impact factor on the sustainable component of an open-pit mine were investigated. In this regard, Angouran Lead and Zinc Mine was chosen as a case study. The correlation matrix of the weighted impact of each impact factor on each sustainable component was then built up based on experts' opinions. Afterward, the magnitude of the influential factors was assigned by experts. The score of the mining activities' impacts on the sustainable development component was calculated based on the

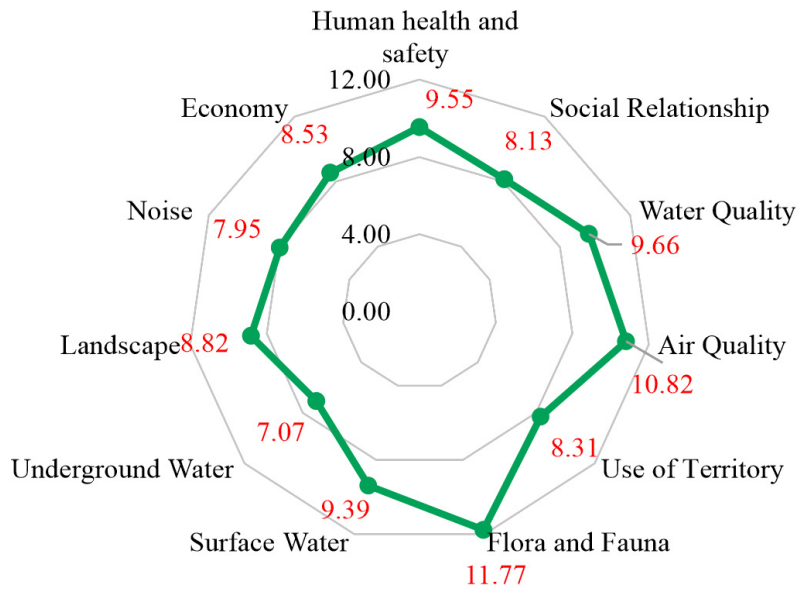

Fig. 4. Percentage of sustainable impacts of sustainability components

correlation matrix. Using the Folchi method, the results demonstrated that human health and safety (30), water quality (30.63), air quality (34), flora and fauna (37), and surface water (29.5) had the most significant effects on the sustainability of Angouran open-pit mine. Finally, it can be concluded that Angouran mine is sustainable due to low components impacts, and there is no need to modify any impact factors.

Acknowledgements. The authors would like to thank the anonymous reviewers and editor for their valuable comments.

References.

1. Chakraborty, M., Ahmad, M., Singh, R., Pal, D., Bandopadhyay, C., $\&$ Chaulya, S. (2002). Determination of the emission rate from various opencast mining operations. Environmental Modelling \& Software, 17(5), 467-480. https://doi.org/10.1016/s1364-8152(02)00010-5.

2. Hansen, Y., Broadhurst, J. L., \& Petrie, J. G. (2008). Modelling leachate generation and mobility from copper sulphide tailings - An 
integrated approach to impact assessment. Minerals Engineering, 21(4), 288-301. https://doi.org/10.1016/j.mineng.2007.10.006.

3. Ekrami, E., Pouresmaieli, M., Shariati, P., \& Mahmoudifard, M. (2021). A review on designing biosensors for the detection of trace metals. Applied Geochemistry, (127), 104902. https://doi.org/10.1016/j. apgeochem.2021.104902.

4. Folchi, R. (2003). Environmental impact statement for mining with explosives: a quantitative method. Proceedings of the $29^{\text {th }}$ annual conference on explosives and blasting technique, 285-296. Retrieved from https://www.scirp.org/(S(i43dyn45teexjx455qlt3d2q))/reference/ ReferencesPapers.aspx? ReferenceID=1190606.

5. Ebrahimabadi, A., Pouresmaieli, M., Afradi, A., Pouresmaeili, E., \& Nouri, S. (2018). Comparing Two Methods of PROMETHEE and Fuzzy TOPSIS in Selecting the Best Plant Species for the Reclamation of Sarcheshmeh Copper Mine. Asian Journal of Water, Environment and Pollution, 15(2), 141-152. https://doi.org/10.3233/ajw-180026.

6. Amirshenava, S., \& Osanloo, M. (2019). A hybrid semi-quantitative approach for impact assessment of mining activities on sustainable development indexes. Journal of Cleaner Production, (218), 823-834. https://doi.org/10.1016/j.jclepro.2019.02.026.

7. Pouresmaieli, M., \& Osanloo, M. (2019). A Valuation Approach to Investigate the Sustainability of Sorkhe-Dizaj Iron Ore Mine of Iran. Springer Series in Geomechanics and Geoengineering, 431-446. https:// doi.org/10.1007/978-3-030-33954-8 50.

8. Laurence, D. (2011). Establishing a sustainable mining operation: an overview. Journal of Cleaner Production, 19(2-3), 278-284. https:// doi.org/10.1016/j.jclepro.2010.08.019.

9. Rahmanpour, M., \& Osanloo, M. (2017). A decision support system for determination of a sustainable pit limit. Journal of Cleaner Production, (141), 1249-1258. https://doi.org/10.1016/j.jclepro.2016.09.205.

10. Pouresmaieli, M., \& Osanloo, M. (2019). Establishing a Model to Reduce the Risk of Premature Mine Closure. IOP Conference Series: Earth and Environmental Science, (362), 012005. https://doi. org/10.1088/1755-1315/362/1/012005.

11. Monjezi, M., Shahriar, K., Dehghani, H., \& Namin, F. S. (2009). Environmental impact assessment of open pit mining in Iran. Environmental geology, 58(1), 205-216.

12. Phillips, J. (2012). Using a mathematical model to assess the sustainability of proposed bauxite mining in Andhra Pradesh, India from a quantitative-based environmental impact assessment. Environmental Earth Sciences, 67(6), 1587-1603. https://doi.org/10.1007/s12665-012-1601-7. 13. Phillips, J. (2013). The application of a mathematical model of sustainability to the results of a semi-quantitative Environmental Impact Assessment of two iron ore opencast mines in Iran. Applied Mathematical Modelling, 37(14-15), 7839-7854. https://doi.org/10.1016/i. apm.2013.03.029.

14. Goodfellow, R. C., \& Dimitrakopoulos, R. (2016). Global optimization of open pit mining complexes with uncertainty. Applied Soft Computing, (40), 292-304. https://doi.org/10.1016/j.asoc.2015.11.038. 15. Ranjan, V., Sen, P., Kumar, D., \& Saraswat, A. (2016). Enhancement of mechanical stability of waste dump slope through establishing vegetation in a surface iron ore mine. Environmental Earth Sciences, 76(1). https://doi.org/10.1007/s12665-016-6350-6.

16. Antoniadis, V., Shaheen, S. M., Boersch, J., Frohne, T., Du Laing, G., \& Rinklebe, J. (2017). Bioavailability and risk assessment of potentially toxic elements in garden edible vegetables and soils around a highly contaminated former mining area in Germany. Journal of Environmental Management, (186), 192-200. https://doi.org/10.1016/j. jenvman.2016.04.036.

17. Birch, C. (2017). Optimization of cut-off grades considering grade uncertainty in narrow, tabular gold deposits. Journal of the Southern African Institute of Mining and Metallurgy, 117(2), 149-156. https:// doi.org/10.17159/2411-9717/2017/v117n2a6.

18. Bouchard, J., Sbarbaro, D., \& Desbiens, A. (2017). Plant Automation for Energy-Efficient Mineral Processing. Green Energy and Technology, 233-250. https://doi.org/10.1007/978-3-319-54199-0_13.

19. Wright, M., Tartari, V., Huang, K. G., Di Lorenzo, F., \& Bercovitz, J. (2017). Knowledge Worker Mobility in Context: Pushing the Boundaries of Theory and Methods. Journal of Management Studies, 55(1), 1-26. https://doi.org/10.1111/joms.12316.

20. Saffari, A., Ataei, M., Sereshki, F., \& Naderi, M. (2017). Environmental impact assessment (EIA) by using the Fuzzy Delphi Folchi (FDF) method (case study: Shahrood cement plant, Iran). Environment, Development and Sustainability, 21(2), 817-860. https://doi. org/10.1007/s10668-017-0063-1.

21. Cuervo, V., Burge, L., Beaugrand, H., Hendershot, M., \& Evans, S. G. (2017). Downstream Geomorphic Response of the 2014 Mount Polley Tailings Dam Failure, British Columbia. Advancing Cul- ture of Living with Landslides, 281-289. https://doi.org/10.1007/978-3319-53483-1_33.

22. Martín-Crespo, T., Gómez-Ortiz, D., Martín-Velázquez, S., Martínez-Pagán, P., De Ignacio, C., Lillo, J., \& Faz, Á. (2018). Geoenvironmental characterization of unstable abandoned mine tailings combining geophysical and geochemical methods (Cartagena-La Union district, Spain). Engineering Geology, (232), 135-146. https:// doi.org/10.1016/j.enggeo.2017.11.018.

23. Sharafi, A., Doulati Ardejani, F., Rezaei, B., \& Sargheini, J. (2018). Environmental geochemistry of near-neutral waters and mineralogy of zinc and lead at the Angouran non-sulphide zinc mine, NW Iran. Journal of Geochemical Exploration, (186), 77-93. https://doi. org/10.1016/j.gexplo.2017.11.020.

24. Zhang, Y., Lu, W., \& Yang, Q. (2014). The impacts of mining exploitation on the environment in the Changchun-Jilin-Tumen economic area, Northeast China. Natural Hazards, 76(2), 1019-1038. https://doi.org/10.1007/s11069-014-1533-5.

25. Statistics Canada, Labor Force Survey; and ISED calculations. (n.d.). Retrieved from https://www.statcan.gc.ca/.

\section{Оцінка стійкості розвитку кар'єру з використанням нової моделі на основі підходу Фолчі}

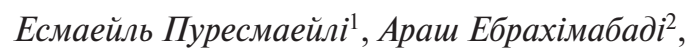 \\ Хаді Хамідіан ${ }^{1}$
}

1 - Кафедра гірничої справи та геології, Каемшарська філія, Ісламський університет Азад, м. Каемшар, Іран 2 - Кафедра нафти, гірничої справи та матеріалознавства, центральна Тегеранська філія, Ісламський університет Азад, м. Тегеран, Іран, e-mail: A.Ebrahimabadi@iauctb.ac.ir

Мета. Відкриті гірничі роботи є одним з основних видів діяльності, що впливають на довкілля, економіку й суспільство у прилеглому регіоні. Отже, важливо дослідити результати цієї діяльності з точки зору оцінки сталості розвитку. Для вимірювання стійкості кар'єру необхідна методологія, що охоплює всі аспекти стійкості проведення гірничих робіт. Мета цієї статті - оцінка стійкості розвитку кар'єру й визначення того, які компоненти вимагають модифікації та більшої уваги.

Методика. Багато дослідників намагалися розробити схеми для вимірювання показників стійкості гірничодобувної діяльності, причому деякі з них є складними, а решта не охоплює всіх аспектів стійкості. У цій роботі для оцінки стійкості розвитку кар'єру був використаний метод Фолчі, заснований на підході багатопараметрового прийняття рішень (БППР). Для цього, перш за все, були досліджені вирішальні фактори та вплив кожного вирішального фактору на стійку складову кар'єру.

Результати. У ході дослідження як приклад було обрано свинцево-цинковий кар'єр Ангуран. На основі експертної оцінки була побудована кореляційна матриця зваженого впливу кожного вирішального фактору на екологічний компонент. Після цього була розрахована величина вирішальних чинників і вплив кожного із них на показник стабільності розвитку кар'єру Ангуран.

Наукова новизна. Результати, отримані на основі використання методу Фолчі, показали, що здоров>я та безпека людей, якість води, якість повітря, флора й фауна, а також поверхня стали вирішальними факторами стійкості розвитку кар'єру Ангуран.

Практична значимість. Нарешті, можна зробити висновок, що кар'єр Ангуран характеризується значним ступенем стійкості через низький рівень впливу діючих факторів, і немає необхідності змінювати будь-які вирішальні фактори.

Ключові слова: стійкість, сталий розвиток, метод Фолчі, свинцево-цинковий кар'єр, Ангуран

The manuscript was submitted 09.06.21. 